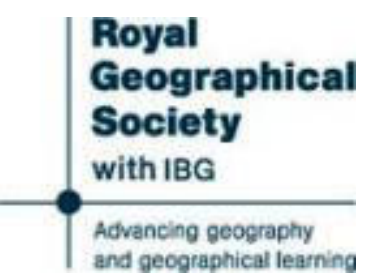

\title{
A Fifth Journey in Persia (Continued)
}

Author(s): P. Molesworth Sykes

Source: The Geographical Journal, Vol. 28, No. 6 (Dec., 1906), pp. 560-587

Published by: The Royal Geographical Society (with the Institute of British Geographers)

Stable URL: http://www.jstor.org/stable/1776048

Accessed: 25-03-2015 08:12 UTC

Your use of the JSTOR archive indicates your acceptance of the Terms \& Conditions of Use, available at http://www.jstor.org/page/info/about/policies/terms.jsp

JSTOR is a not-for-profit service that helps scholars, researchers, and students discover, use, and build upon a wide range of content in a trusted digital archive. We use information technology and tools to increase productivity and facilitate new forms of scholarship. For more information about JSTOR, please contact support@jstor.org.

The Royal Geographical Society (with the Institute of British Geographers) is collaborating with JSTOR to digitize, preserve and extend access to The Geographical Journal. 
I am afraid I did not make myself quite clear about the question of the longheaded people in the Balkans. I had to mention them, and the thing would have borne considerable expansion; but the difficulty which Dr. Evans feels, and we all feel, is this: How is it that you have a well-marked and very persistent patch -we do not know that it is more than a patch-of long-headed people among the Bosnian tombs at a period so very much later than that at which we have wellmarked broad-headed people so much further west? Either the broad-beaded people came by way of the north route out of Asia, or they came by way of the south route. I hope that I have satisfied others besides myself that the north route was closed. If they came by the south route, how is it that they have left this patch, or that this patch of broad-headed peoples in Balkan lands has survived? My suggestion for dealing with that difficulty is to suppose that the tomb-type is of significance ; and that, thanks to their tomb-type, one is justified provisionally in regarding these Bosnian long-heads as an intrusion (of a kind which has frequently happened since) of pastoral people out of the steppes into the Balkan peninsula who have pushed considerably far afield into an area where broad-headed man did not follow, and where possibly he never had been. I suggest that the reason is, that (so far as we know) the geology and geography of that area are such as to make it neither forest nor lake-land.

Dr. Shrubsall's point about the Guanches is explained, I think, if one interprets Deniker's "Atlantic-Littoral " type as the result of the intrusion of "Dinaric " tall short-headed folk among a "Mediterranean" population, long-headed and short. Thus interpreted, the distribution of the "Atlantic-Littoral" type reveals itself as a series of stepping-stones between the south-western fringe of "Dinaric" man and the Guanche and other short-headed outliers in north-west Africa. That is why I have included the "Atlantic-Littoral" people in my map-analysis of Deniker's conclusions : it is the south-western counterpart of his "Eastern" race in central Russia, and his Russian patches of "Cevenoles" are the analogue of the Guanches.

Dr. Wright's suggestion as to the comparative study of funeral rites leads to very instructive results already; but one of the points still in suspense is, how far funeral rites can be regarded as really deep-seated characters of human groups. One can learn to bury one's dead a fresh way; one cannot learn a fresh shape for one's head. In the case of the southern analogues of the Kurgans, even, I only venture to adduce them in this argument because I think there is sufficient evidence on the physical side to justify the assumption of early long-headed intrusion southwards from the Kurgan area proper.

\section{A FIFTH JOURNEY IN PERSIA.*}

\section{By Major P. MOLESWORTH SYKES, C.M.G.}

After leaving Rizáb we rose steadily to the watershed, which was almost level for about 2 miles. We then descended close under a red and yellow hill, where the steep ravine was almost too much for the labouring team; but at last that obstacle too was left behind, and, finally, after a march of 37 miles, Sághand was reached. Late at night

* Read at the Royal Geographical Society, June 18, 1906. Map, p. 429. Continued from p. 453 . 
one or two beggars who had not been worth " trussing" arrived, from whom we learned the fate of our fellow-travellers, and were amused to hear that we had been cursed freely by the bandits for interfering with the exercise of their profession on the advanced caravan, which we had, quite unwittingly, protected by our presence.

The crux of this section of the journey was a 33-mile waterless stage from Robat-i-Kbán to Chashma-i-Shuturán, with a belt of sandhills which commenced at the twenty-second mile. To give our horses every chance, water and forage were left by the advanced camp at the waterless caravanserai of Robát-i-Sirka, situated close to two redbrick obelisks, said-and probably with truth-to date from Safavi times. There, after five hours' rest, the carriage, drawn by four horses abreast, started to cross the dreaded sandhills, which rise to a considerable height and form a fitting boundary between the deserts of Yezd and Tabas. Thanks to the precautions taken, and to the fact that the carriage was almost empty, the horses were just able to master the steep gradients, and at sunset, wearily enough but without a breakdown, the whole party had reached camp, accompanied by two travellers whom we had rescued, inarticulate from thirst, in the middle of these shifting sands, which during a gale must indeed be dangerous. Beyond Robat-i-Khán, the carriage, as apart from the horses, underwent its most severe trial. The route was quite impracticable, as being too narrow for wheels, and the river-bed constituted the only possible route; but this in parts was so narrow, owing to the huge boulders, that it is marvellous how the carriage passed. In places rushes were made, in which we all aided; but elsewhere the horses were driven up until the wheels touched the obstacles, when judicious slewing round of the back portion of the carriage had the desired effect. Throughout one admired the resource shown by the coachman, who was an Azerbaiján Turk, and differed as much from the voluble Persian as an Englishman does from an inhabitant of Tarascon.

Eleven stages, or 220 miles, were at last accomplished, and our interest was excited to the full when we looked down upon Tabas, one of the most remote towns of Irán. To appreciate the oasis, it should be approached, as on this occasion, after many days of wearisome and monotonous travel across the Lut, during which no greenery had been seen, and the daily provision of water and forage had ever been the prevailing question. The surroundings of the town, too, are arid, the terrible desert stretching to the south for hundreds of miles, its white glistening surface being broken in the far distance by the Naiband range, which I had explored twelve years previously. With our eyes filled to repletion with this blighting, palsying waste, the sight of Tabas was indeed refreshing, and when, skirting the town wall, we drove for more than a mile up an avenue bordered on both sides by mulberries, elms, willows, and palms, we revelled in this wealth of fresh greenery, which 
was accentuated by the murmur of running water and the smell of beans in flower, surely one of the most delightful of odours.

Tabas, known as "the Gate of Khorasán," was termed Tabas-atTamr, or "Tabas of the Date Palm," by the Arab geographers, to distinguish it from Tabas-al-Unnab, or "Tabas of the Jujube Tree," which I described in a former journey* as being situated some three stages to the east of Birjand, and which is now known as Tabas Sunnikhána. The date of its foundation is unknown, but it is connected by place-names with Parthian times. This dynasty is termed Ashkáni by the Persians, a word represented by the classical Arsaces, which was the title of the royal family. I may incidentally remark that the Chinese envoys of the second century B.c., who were the first to open up communications between the Far and Middle East, refer to the King of An-Sih, which fact is of considerable interest. $\dagger$ In the Tabas district is Deh Ashk, and also Darra Ashkán, which names corroborate the above theory. Tabas was conquered by the Caliph Osman, as were also Káin and Kuhistán, in A.H. 31 (651). Later on it became a centre of the famous Ismaili sect, whose extraordinary tenets are responsible for the word "assassin," and for the true story of the "Old Man of the Mountains." Marco Polo did not, I think, visit Tabas; but I have recently dealt with this question in the Geographical Journal. Here it suffices to state that the great traveller describes his route as far as Kubanán, some five stages to the north of Kermán. Thence I originally thought that he crossed the Lut to Tabas, but my inquiries have tended to prove that Ser Marco, in all probability, travelled via Naiband to Tun by a route which keeps to the east of Tabas. Tabas, in the eleventh century, became known as Tabas Gílaki, after a chief who conquered it, whereas Tabas to the east of Birjand was termed Tabas Masinán. But I must not allow myself to be led away into an historical dissertation, and will pass on to the eighteenth century A.D., when Nádir Sháh, in return for services rendered when lost in the Lut, conferred the district on Ali Morád Khán, an Arab of the Zangui tribe, which is connected with the Khuzái tribe, to which the amirs of Káin belong. The same family still governs the district, although their position is far different from that held by them after Nádir Sháh's death, when the ruling chief made a bid for the throne of Persia.

Before describing the little town, I propose to make a short reference to the district. Tabas and Tun, the division to the east, together with Gunabád to the north-east, unite to form the governorship, Tabas being the poorest of the three divisions, the latter two of which $I$ bave

* Vide Geographical Journal for February, 1902.

† Vide 'Chinese Knowledge of Early Persia,' by E. H. Parker. Asiatic Quarterly, January, 1903.

$\ddagger$ Vide Geographical Journal, vol. 26 (1905), p. 462. 
previously described. Situated on the edge of the Lut, and growing but scanty crops, which do not provide more than six months' food for its population, Tabas depends mainly on its date palms and orange groves, the produce of whioh is highly prized in upland Khorasán. As is general in Persia, the population is divided into dwellers in villages and nomads. The latter are all of Arab extraction, and possess enormous flocks of sheep and camels." The town of Tabas, which is situated at an altitude of about 2000 feet, is walled, and contains various bazaars. But the chief, if not the only, object of interest is a fine column which rises to a height of some 200 feet, and is known as the Minár Kabir, or the "Great Minaret." It is constructed of brick set in various patterns,

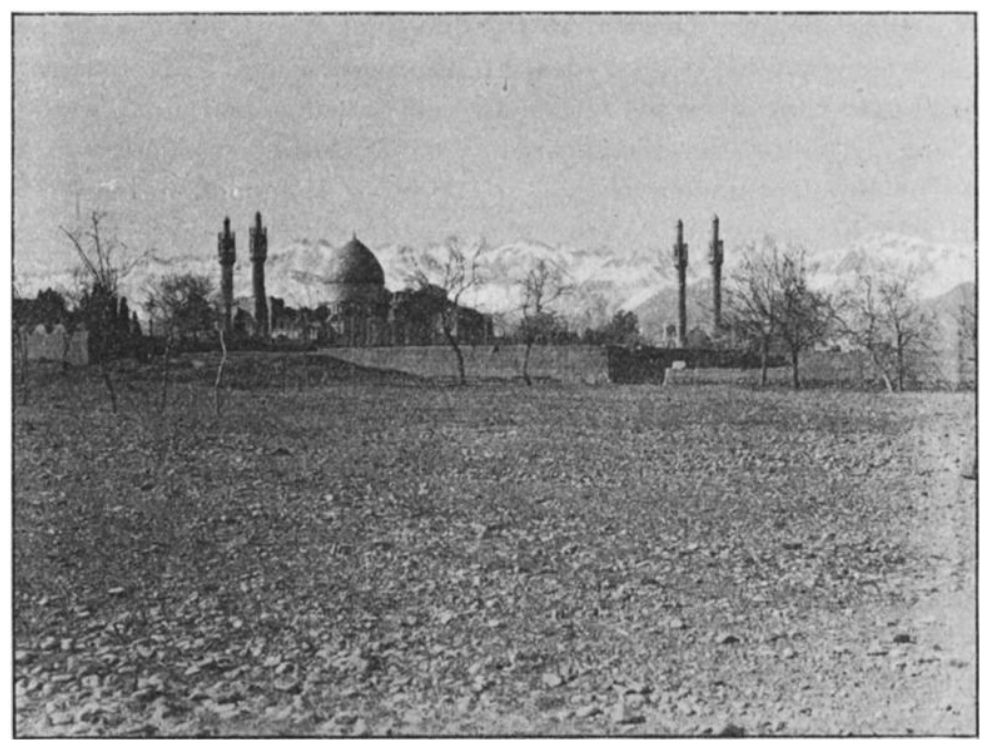

THE MÁHUN SHRINE.

and has two bands of a Kufic inscription running round it: apparently it dates from Seljuk times. The origin of these columns bas been much discussed by travellers in Persia, but as they all possess a staircase, it is, I think, extremely probable that they served as watch-towers primarily, and also as beacons. In the wide plains of Persia, where surprises were the one thing to be especially guarded against, the utility of the watch-towers is evident. Modern Tabas, owing to the cessation of the Turkoman and Baluch forays, has partly deserted the cramped bazaars and spread east on both sides of the avenue

* The nomads are: Chubdári, 200 families; Khanjari, 250 families; Arab, 200 families. In the winter they graze near Tabas, and in the salt country to the north. In the summer they move to the hills in the Tun and Gunabad districts. 
referred to above, where the population, estimated at 8000 , occupies gardens. Two miles to the west is the strine of Musab ibn Jafar, who is locally known as Shahzáda Sultán Husein. This was, I believe, the site of a still more ancient Tabas, it being comparatively easy to change the position of a town situated in a plain which is served by irrigation streams. The dome of this shrine is said to have been built by Mir Ali Shir Kbán, Sheibáni in A.H. 950. To conclude this brief sketch, Tun and Tabas are regarded as the least delectable of the districts of Khorasin, and "Go to Tun and Tabas" is by no means a polite remark.

The evening of our arrival I was welcomed by the Imád-ul-Mulk, who is not only a lineal descendant of the old chiefs of Tabas, but, on the distaff side, can boast that the blood of Nádir Sháh runs in his veins. He gave me a good deal of information about his district, and I also heard that when his father died, some wonderful old jewellerythe loot of Delhi-had disappeared. One of these pieces, my informant stated, was an ornament with four enormous diamonds, on which were incribed the names of Akbar the Great and his three successors. Tabas struck me as very much out of the world; but there is now a weekly post with Meshed, and I am agitating for it to be continued to Yezd, as in Eastern and Central Persia there is no south-to-north postal service, so deadly a barrier is the Lut.

We had now accomplished about two-thirds of our long journey, and as we were not only marching north-east, but also were approaching districts less low-lying than Tabas, we started, after two days' rest, with the feeling that the worst had been left behind. We crossed the low range bounding the plain of Tabas to the north, and descended into a district of great Kavir, by the side of which the Tabas nomads were grazing flocks of sheep much larger than any we had seen in South-east Persia. Indeed, everything was by comparison green and fertile, although only practised eyes would perhaps have noticed the great difference. At Yunsi we joined the direct Kermán-Meshed route. Lying in the midst of a level salt plain and on the banks of a salt kál, or river, this village is one of the most depressing places in Persia; it is referred to by Sir F. Goldsmid * in connection with a legend that the prophet Jonah was thrown up at this spot, and took refuge under a gourd. A few stages later we traversed the last of the salt plains and reached the fertile district of Mahavalát, which is the centre of a thriving silk industry, and is famous for its melons. It lies on the skirt of the high central range of Khorasán, and from it as far as Turbat-i-Heideri, which was reached on May 3, there was a steady rise throughout. The district of Turbat-i-Heideri was originally known as Záva, of which the chief town was termed Bishak. To-day

* Vide ‘ Eastern Persia,' p. 250. 
Záva is the name of a flourishing village one stage to the east of the town of Turbat-i-Heideri, but has ceased to give its name to the district. Rukhh, by which name the northern portion of the district was known in mediæval times, is also no longer used. The nomenclature of the capital town of the district is derived from Heider, who was the founder of the sect bearing his name. This holy personage, in the seventh (thirteenth) century, became famous for his endurance, inasmuch as during the summer he walked about in fire and dressed in felt, whereas in midwinter he lived in the snow. Heider, who is generally better known by the title of Kutb-u-Dín, or "Pole of the Religion," is buried in a dome built over his turbat, or tomb, and this is the origin of the name. Less than a century ago, Ishak Khán, a Karái chief, seized the district, and for many years the town was termed Turbat-i-Isá-Khan. To-day, however, the original name is almost entirely used, and Ishak is forgotten. At Turbat-i-Heideri I joined the route followed by me in 1893. At that date $I$ put up at a caravanserai, but on the present occasion we were welcomed to a comfortable consulate, and thoroughly enjoyed the hospitality of Captain J. Watson. The little town has grown considerably of late years. It possesses remarkable nodality, as roads from Meshed, Herát, Seistán, Kermán, Yezd, and Turshiz all unite in the little walled bazaar, which is estimated to possess 8000 inhabitants, and is the centre of the silk and Baluch * carpet trade. To resume, the last section of rather less than 90 miles brought us to Meshed of the golden dome, where our march of over 700 miles, accomplished at a rate slightly exceeding $16 \frac{1}{2}$ miles per diem, was brought to a successful termination.

\section{V.}

For some months after reaching Meshed the press of official work prevented me from examining the surrounding country; but late in the summer I made a flying trip to the district of Kuhpaia to the west, across which runs the direct route to Nishapur. This district is extremely historical, and among other claims to interest is the fact that in it is situated one of the original fire temples founded by Zoroaster, which has never been identified. Of this, one of the most important sites in Khorasán, I have some information, and I hope, during the course of the next few years, to prove my information correct, but on the present occasion there was not sufficient time at my disposal. To resume, in the first place we drove to Gulistán, at the entrance of the Nishapur range. This village is composed of houses running to three storeys, with windows cut in the main wall, and

* There are 1700 families of Baluchis in the Turbat-i-Heideri district. So far as they themselves can tell, they have come north from the confines of Baluchistán during the last century. 
presents a most curious and picturesque aspect. Below runs a river, across which is constructed one of the very fine old dams which abound in Khorasán. The legend runs that its builder buried enough gold in its foundations to reconstruct the entire work should a flood sweep it away. Passing Gulistán, we continued our journey up the valley to Turgabeh, a corruption of Turuk Oba, or " the Settlement of the Turks," where we found our horses awaiting our arrival. Thence the river-bed was struck, and our senses were charmed by a valley with glades, trees, and greenery, the like of which I have never seen on the Irán plateau; and yet all was northern in character, from the elder bush to the poplar, and from the sweet-savoured thyme to the wild rose. In short, one felt in surroundings such as would befit the "Midsummer Night's Dream." Six miles above Turgabeh is the large village of Jághark, * which is a typical hill village. Lining both sides of the precipitous valley, the houses, constructed of the rounded stones from the river-bed, rise to a considerable height, and are remarkable for their overhanging eaves, which are carved and painted, and for their rough windows of wooden latticework. The lower storey contained the farmyard, and the dwelling-rooms were perched above. Trees were everywhere, and often formed part of the wall, and might even be seen growing up through a roof. The setting of these truly charming villages is enhanced by little cascades, which tumble down the mountain-side and and to the volume of the murmuring brook. But yet the name of Jághark is ominous, and signifies "the Place of Drowning," and every now and then a storm in the hills produces a flood with such disastrous rapidity that on one occasion an entire regiment was drowned in the narrow gorge. Jághark, too, possesses a curious legend, in which reference is made to a ship floating on its waters. These legends are also crystallized in place-names, such as Langar, $\dagger$ signifying an anchorage, and Yunsi, which commemorates the prophet Jonah, and one is tempted to believe that they are the echo of a far-off rumour of the days when there was an inland sea in Persia. Passing through the busy bazaar, and then the tea-shops, consisting of fantastically shaped platforms built on piles over the stream, the ascent became steeper, the atmosphere grew fresher, and the valley narrower, until our guide led us by a tortuous track up through delightful orchards to a spur where the greenery suddenly terminates and gives place to the naked hillside covered with slate débris. Below this a little side valley ran up to a stream, and so much impressed was I with its charm and remoteness that I decided to convert it into a hill station for Meshed; and, indeed, no more ideal spot is conceivable, as a cottage perched on this spur overlooks a bend of the valley which forms a sea of greenery, and yet is raised

* Vide Yate's ' Khorasan and Sistan', pp. 348 et seq.

$\dagger$ Langar is situated one stage to the north-west of Turbat-i-Shcikh-Jám. 
above the unwholesome damp of the valley, and far from the still more baneful mosquito. We spent the night in the champagne air of the hillside, and early dawn saw us on the road bound for the Dar Rud pass. We crossed and recrossed the brook repeatedly and, as we ascended, the sides of the valley became precipitous, and the dense growth of plane and poplar was succeeded by scanty willows. These too in time ceased, and we thenceforward rode up a stony, forbidding valley to a point where the valley bifurcates at a small stone caravanserai. The climb up the pass was long, but easy, and some four hours after leaving camp, we reached the summit at an altitude of 9400 feet, or 4000 feet above our camp, and more than 6000 feet above Meshed. To the south the range was narrower, probably owing to the fact that

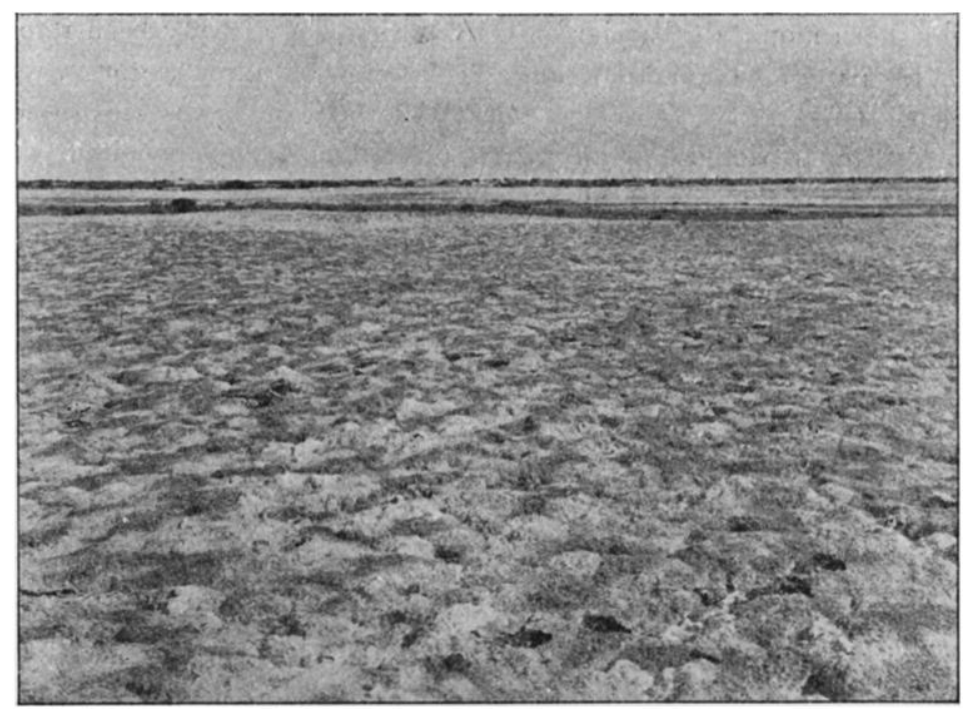

KAVIR, OR SALT GROUND IN THE LUT.

the snow melts sooner on the southern slope and cuts a deeper channel, whereas on the northern slope the snow lingers late into the year. We were looking on to the plain of famous Nishapur, but a haze brooded over everything, and nothing was visible in that direction Looking back in the teeth of a furious gale, and following down the wide fertile valley of the Kashaf Rud, * the dark green of the gardens surrounding Meshed was easily discernible. But the golden dome remained invisible, until, gazing intently, a fitful flash as if of summer lightning flickered and again vanished, and it was thus that the glory of the Persian religious world was revealed to us from afar. The summit of the range consisted of rolling downs, with a few elevated mountains.

\footnotetext{
* Kashaf signifies " a tortoise."
} 
One of these to the north-west is termed the Luk Tarsa, or "the Fearful Camel." Behind it was Pishána Fil, or " the Elephant's Forehead." The return down the valley to our camp and thence back to our home on the following day was speedily accomplished, and we agreed that Meshed compared more than favourably with Kermán in regard to its summer retreats, which are within an easy ride of the city, and would be an acquisition to any capital in the world.

In the autumn of 1905 , the British minister, Sir Arthur Hardinge, traversed Khorasán on his way to England viâ Trans Caspia and, after the attractions of Meshed had been exhausted, it was arranged that a visit should be paid to the most famous fort of Central Asia, which is known as Kalát-i-Nádiri. Leaving the capital of Khorasán early in September, we marched due north to Rizván, situated on the skirts of the northern mountain barrier of Irán, which has already been referred to in this paper. The actual range is entered by a rocky gorge, which forms a fitting portal to rock scenery of stern and awesome grandeur certainly unsurpassed in any part of Persia $I$ have visited. The track ran up the river-bed, which was subsequently quitted, and rose across some low hills to the upland village of Kardeh. From this village we started off betimes, escorted by some horsemen who belonged to the Chulái, a Turkish tribe, settled in these parts by Tamerlane. They apparently talked Turkish among themselves, but understood Persian. Their dress closely resembled that of the Turkoman, except that their sheepskin bonnet was cut lower. They struck us as fine, hardy men of a manlier type than the Persians. The whole district is called Chulái Khána, the Kara Dagh constituting its northern boundary. Nine miles above Kardeh we halted to photograph and examine an inscription which the late Mr. Ney Elias had had copied. It is situated on the left bank of and well above the river, and consists of ten lines, which measure 5 feet 6 inches by 3 feet 2 inches. The inscription, which is beautifully incised and quite legible, is to the effect that in A.H. 915 Abul Fath Mohamed Sheibáni defeated a Persian force in this neighbourhood.* Several photographs were taken, most of which were successful, and we continued the ascent past a completely round white cliff. It is known as Panj Mana, or " the Five Stones," $\dagger$ and is connected with a far-fetched story of a courtier who apparently offered to put the weight with it. Eighteen miles from Kardeh we quitted the main valley and scrambled up the very steep and boulder-strewn narrow gorge known as the Zo-Pir-i-Zan, or "Valley of the Old Woman." However, the gorge in question was not so bad as the one

* Mohamed Sheibáni was almost the last warrior of the house of Chengiz, and the founder of the Sheibáni dynasty and of the Uzbeg kingdom, which lasted until Khiva, Khokand, and Bokhára fell before the onslaught of Russia some thirty-five years ago.

+ A man is of various weights, but the Tabriz man, which is most generally used, weighs about $6 \frac{1}{2} \mathrm{lbs}$. 
bearing a similar name in South Persia, and, above it, we emerged on to rolling hills, traversing one of the two great parallel spurs into which the Hazár Masjid range divides, the second being known as the Kara Dagh, or "Black Mountain." The descent across this second range was extremely trying, and its name of Diwa Boíni, or "the Camel's Neck," * struck us as most appropriate. At last we reached Várdeh, only to find that the advanced camp was still trying to find a way round. However, we ultimately obtained all that was necessary, and settled down for the night, after accomplishing a particularly trying march. The following day we crossed yet another range, and descended a valley with superb rock scenery, great ribs of slate rising precipitously from the sullen gorge. A good photo of the rocks in the Darband-i-Gaur, or "the Fortified Gate of the Infidel," as it is termed, was secured, and the journey was resumed down the valley, which gradually opened out, but in front all further progress appeared to be barred by mile upon mile of sheer precipice. This is the southern wall of the Titanic fort of Kalát-i-Nádiri, which runs in an almost unbroken line as far as the eye can reach. Before the visit of Sir Arthur Hardinge to Khorasán, the Governor General had promised to arrange for my entry into this somewhat jealously guarded stronghold, in which no previous consul general had been permitted to set foot, although Sir Charles MacGregor and Colonel A. C. Yate were admitted to it thirty and twenty years ago, and there is no reason for debarring a sight of its wonders to travellers. At the same time, on nearing the historical fortress, I felt considerable anxiety as to whether the governor would obey the Asaf-u-Dola's orders, as he is appointed direct from Tehrán, and is thus more or less independent of the Governor General of Khorasán. It was, consequently, with much relief that I sighted a reception party headed by the governor's son, under whose guidance the minister was escorted to the Argawán Shah darband, outside which our camp was pitched.

I now propose to give a brief description of the famous fortress which we were to enter on the morrow. Its shape exactly resembles the profile of a wild boar, its general direction running west-north-west. The southern wall, already referred to, is the most uniform in appearance, and some 15 miles in length. It is broken at the Darband-iArgawán Sháh, which represents the boar's mouth, and again, at the south-east extremity, there is a second entrance known as the Kushtani darband. This latter is situated on a long narrow spur in which the fortress terminates to the south-east, thus continuing the extraordinary resemblance referred to above. The whole of this stupendous wall rises almost sheer to an altitude of some 1500 feet. Of this perhaps one-half or two-thirds of the distance is climbable, but the crest is

$*$ The names in thig
No. VI.-December, 1906.] 
composed of a black rock, possibly basalt, resembling in shape a wedge, which is so narrow on its inaccessible summit that it would be almost impossible to walk along it. Continuing in a west-north-westerly direction from the darband of Argawán Shah, "the snout" of the fortress is most clearly defined, and the boar's "eye" is the Dehchi entrance on the north. This side rises at least 2000 feet above the valley, but it struck $m e$ as less inaccessible. At the same time, it is only fair to mention that I inspected it from the crest only. The boar's " back" is broken by the Deh Nafta darband, and through it the river, which enters Kalát-i-Nádiri by the Argawán Shah darband, flows down to water the fertile oasis of Doshakh, the ancient Abivard. It is known as the Nafta river.

On the east side there is the fifth darband of Chubbast, and, as stated above, the fortress terminates in a narrow spur to the east. So much for the circumference, which is perhaps 60 miles in perimeter. I now turn to the interior. The life of Kalát centres in the narrow valley, some 12 miles in length, which runs approximately from west to east between the Argawán Shah and Nafta darband. Almost throughout there is a narrow strip of cultivation which supports perhaps one thousand inhabitants. Elsewhere, there are three or four small villages dependent on rain crops, the inhabitants of which bring the total up to two thousand. What particularly struck me was the hilly nature of the interior. Hills are everywhere, chief among them being the Kuhi-Bába-Kumeili, which rises to over 6000 feet, and more or less fills up the south-east corner. Elsewhere, too, once the narrow valley is left, the rough track winds across a maze of low hills, so much so that internal communications are extraordinarily difficult. The altitude of the main valley is about 3000 feet, and, partly owing to its shut-in condition, it is extremely hot in summer. The main water-supply is drawn from the river, but there are a few small springs of good water. The climate is unhealthy, and the mosquito so active that every one sleeps under curtains, the only corner of Persia where I have noted this custom.

The history of Kalát, which I have collected from various Persian chronicles, is, as might be expected, of considerable interest. In Firdausi's great epic, known as the "Sháh Náma," the district is referred to as Kalát and Charam, the latter being the name of an important village, still existing some 6 miles to the west of Kalát. In it a grim tragedy was enacted on the occasion of the invasion of Turán or Central Asia by the forces of Kei Khusru, a semi-historical monarch of Persia. It was inhabited by his half-brother Farud, who was independent, and the Shah enjoined upon Tus, his commander-in-chief, the necessity of avoiding the district. However, it was found that the alternative routes led through deserts, and the Persian army perforce entered the gorges to the south of Kalát. Farud, hearing of the approach of a mighty host, took up his position on a lofty crag and 
watched the army defile below him. He was accosted by the hero Bahrám, who, on being shown the mole on Farud's arm, which proved him to be of Keiánian stock, reported to Tus that it was the Shah's brother. Tus, however, cherished sinister designs, and, wishing to sack Charam, refused to acknowledge the identity of Farud, who was attacked. After slaying various Persian champions in Homeric style, the hero retreated to the fort, whence he shortly afterwards sallied forth and gave battle until the whole of his force was exterminated and

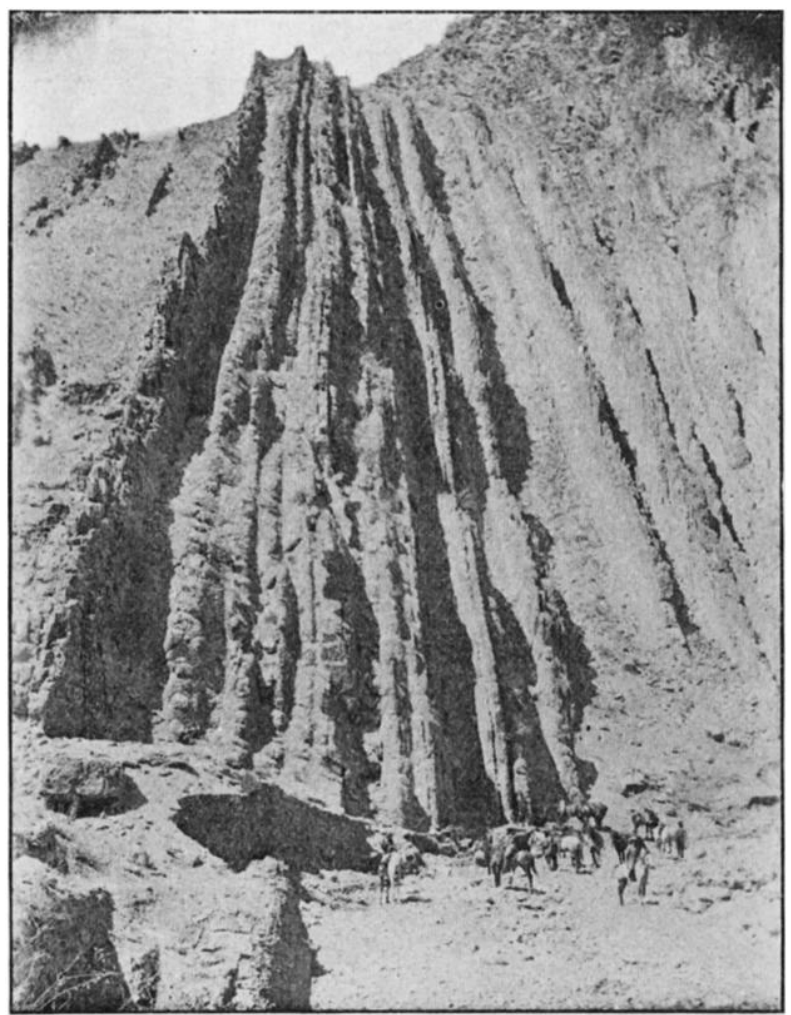

SLATE FORMATION IN THE DARBAND-I-GIAOUR.

he himself was mortally wounded. Returning to his fastness with difficulty, he was received by his mother, who fired the treasury and hamstrung the horses. The women committed suicide by throwing themselves from the top of the fortress, and finally Farud and his mother killed themselves. Tus burst in the gate, to find nothing living inside, but merely a mass of ashes on which to satiate his thirst for plunder. From the above it does not appear that Kalát was renowned for its natural strength in the tenth century of our era, when Firdausi 
lived, but in A.H. 682 (1283) Arghun, termed Argawán by the Persians, took refuge in the fastness after suffering defeat at the hands of his uncle, Sultán Ahmad. He was besieged, but without success, and, using the impregnability of Kalát as a lever, he opened negotiations with the nobles of Tabriz, and finally won the throne of Persia. This constitutes the first historical siege of Kalát.

But it was not until blood-drinking Tamerlane strode across the stage of Asia that Kalát won its imperishable fame and the title of the greatest fastness of the Middle East. The "Lord of the Conjuncture of the Planets," as he is termed, found Kalát in the possession of a certain Ali Beg, and attempted its capture by surprise, but in this he failed, although he seized many flocks of camels and sheep. He then formally invested what is now known as the Nafta darband in person, his amirs attacking the other entrances. Some Badaksháni hillmen discovered a track, up which they climbed the cliff, and matters looked black for the defenders; but Ali Beg proposed a meeting to arrange the terms of surrender, and took advantage of its being granted to break down this track. Fourteen general assaults were then delivered, but were repulsed without difficulty, and the world conqueror was forced to retire defeated. Two years later, Amir Sheikh Ali, a nephew of Tamerlane, escaladed the natural barriers, but, once there, found himself caught, and when his arrows were expended was forced to surrender. Shortly afterwards plague broke out, and wrought such havoc among the defenders, that Ali Beg surrendered and was put to death.

Kalát apparently does not again figure large in the history of Khorasán until the star of Nádir Sháh, the last great Persian conqueror, rose on the murky horizon, and in a few years restored to Persia her dignity and prestige, which the Afghan invasion had for a time shattered. Nádir Sháh was a glorified robber who was born in the neighbouring district of Darra Gaz, and throughout his career cherished a strong affection for the fortress which was thenceforward to be known by his name. After his glorious triumphs in Afghanistán, in India, in Bokhara, and in Khiva, the dread Afshár repaired to Kalát in A.s. 1740 , and began its fortification by building the works which we saw. He cherished a dream that one day he would retire to spend his closing years in this safe retreat, and it was here that he stored the untold millions of India, with the famous diamond, the Daria-iNur, or "Sea of Light." His family, too, was sent to live in the same fastness. Fate, however, never permitted the realization of these idle dreams, and Nádir Sháh was assassinated in A.D. 1747, and fell, cursed for his cruelties by the whole nation. A nephew, Ali Kuli Khán, was elected his successor, and his first act was to send a band of Bakhtiári horsernen to extirpate the tyrant's brood and seize the treasure at Kalát. The carelessness of the garrison, a member of which 
had neglected to pull up the ladder, by which means alone there was communication with the outer world, made everything easy, and in a few hours every male descendant of the conqueror of India was put to the sword, and the treasury was looted. One scion of the house, Sháh Rukb, a grandson of Nádir Sháh and a mere boy, was alone spared, in case the nobles clamoured for a member of the royal house, and with this grim tragedy the description of Kalát-i-Nádiri may fitly bo brought to a close, just as grim tragedy ushered it on to the stage of history.

I now return to our journey. We quitted camp at dawn on the following morning, and were soon riding between two precipitous cliffs,

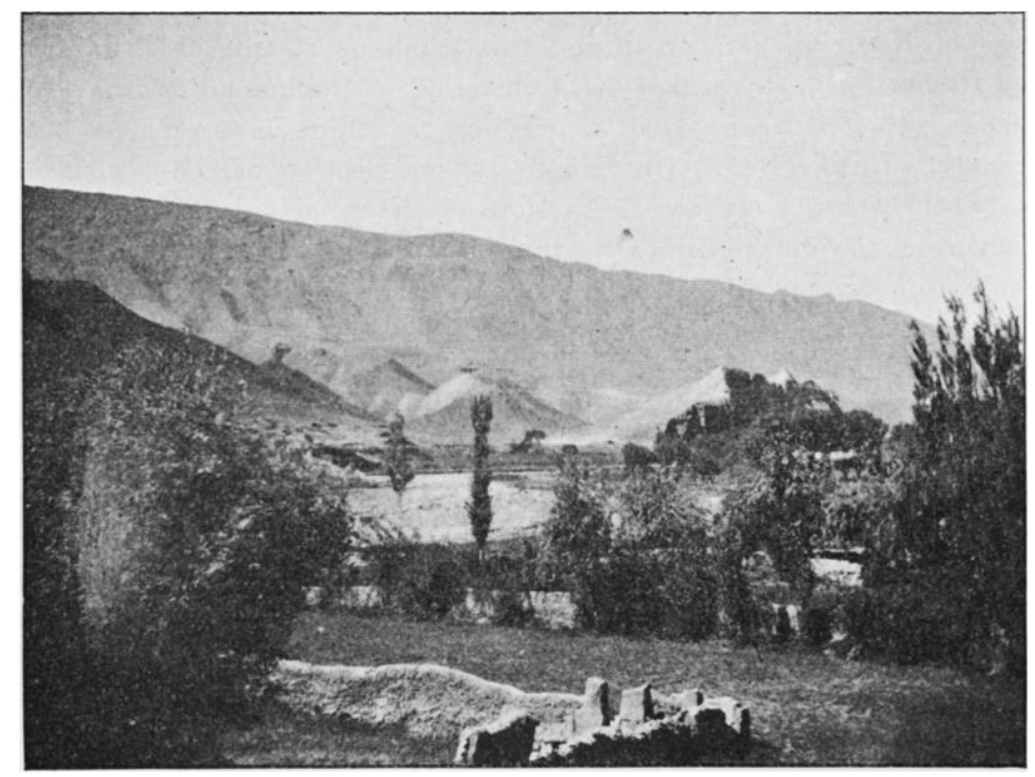

INTERIOR OF KALÁT-I-NÁDIRI, SHOWING SIDE OF NATURAL WALL.

which frowned down upon the sunless shingle of the river bed. The Hebrew writer's "Who will lead me into the strong city? and who will bring me into Edom?" came into my mind as we entered the fort, and I recollected that Edom, like Kalát-i-Nádiri, was a natural fastness of extraordinary strength. The actual darband had been recently injured by a flood, and is by no means strong, but at every turn towers or forts supplemented the hand of nature, the whole constituting an impregnable position if held by a resolute force. The darband is named after Argawán Sháh, who was referred to above. It is of more than usual interest to recall that it was this monarch who despatched an embassy to China, to the court of Kublei Kaán, and was thus instrumental in procuring the return of Marco Polo to Europe, as he alone was 
acquainted with the sea route from China to Persia, and was also deemed sufficiently trustworthy to take charge of the lady Kokachin, who, according to the illustrious Venetian, was " moult bele dame et avenant." Arghun Sháh, furthermore, sent embassies to the pope and to the kings of France and England. In return, Edward I., in 1290 A.D., accredited Geoffrey de Langley to visit the Moghul, with a gift of " some gerfalcons and other jewels of our land." We passed the ruined darband, and, a short distance beyond it, stopped to examine an inscription, which is cut in the cliff and beautifully incised. As may be imagined, this record was of great interest, and, after failing in the first attempt, I have secured an excellent photograph of it. The inscription is partly in Persian and partly in Turkish, and is not completed. However, the name of Nádir appears on it, and this alone, apart from the character and decoration, proves that it is chiselled in the honour of the great Afshár, and is not connected, as previous travellers have reported from hearsay, with Arghun. Unfortunately, one section of the inscription has been worn away by the action of water; but I have hopes of recovering the defaced lines, as there is an old gentleman of ninety, a resident of Kakha, who is said to possess a copy of it. So far as it is decipherable, the inscription consists of praise of God and Mohamed, with a reference to Nádir Sháh. To resume, we emerged from the gorge at the village of Argawán Shah, which is inhabited by Jaleiir and Gerashlu Turks, and thenceforward there was a continuous strip of cultivation, with numerous gardens. After passing a ruined icehouse, whence a track leads to the Dehchi darband, we skirted a hamlet, termed Khwárizm Mahalla, which is peopled by a few families from Khwárizm, or Khiva, planted by Nádir Sháh, who, like the monarchs of Chaldea, transported tribes from one side of Central Asia to another. Finally, 4 miles from our camp, we reached the governor's residence, known as " Kabud Gunbad," or the "Blue Dome," a name derived from its mosque.

We returned the call of the Jalil-ul-Mulk on historical soil, for he received us in the garden, in which is situated the Imárat-i-Nádir, or "Building of Nádir." This consists of a central dome some 90 feet in height, constructed of a variety of stone resembling Devonian sandstone. The interior of the dome was some 50 feet in diameter, and there were traces of decoration in gold, blue, and black. This central dome of fluted pillars was surrounded by four sets of rooms, each consisting of an arch with a chamber on either side. The whole was cased externally with marble, which, with the utter disregard to means displayed by Orientals, was quarried in Urmia, near Tabriz, and transported some 1500 miles from the western to the eastern frontier of Persia by forced labour, and, as Sir John Malcolm testifies, at the cost of much human misery. The stone panels are decorated with exquisitely cut trees and birds chiselled in relief, but some of the panels 
are plain, thus presenting an unfinished appearance. Beneath are extensive vaults. This was the famous treasury of Nádir Sháh, and the cellars, rather more than a century and a half ago, contained more bullion and wealth than any conqueror has perhaps amassed since Alexander the Great rifled the hoards of the Achaemenians. The whole is interesting rather than striking; indeed, the design is mean and betrays no grandiose inspiration, such as would be befitting to a thesaurus which included the Dariá-i-Nur, or the still more famous Peacock Throne. After concluding our inspection, we rode to the northern wall, which, unlike the southern, is hidden from the valley by an interior range. Two hours of steep ascent to an altitude of 4500 feet brought us to

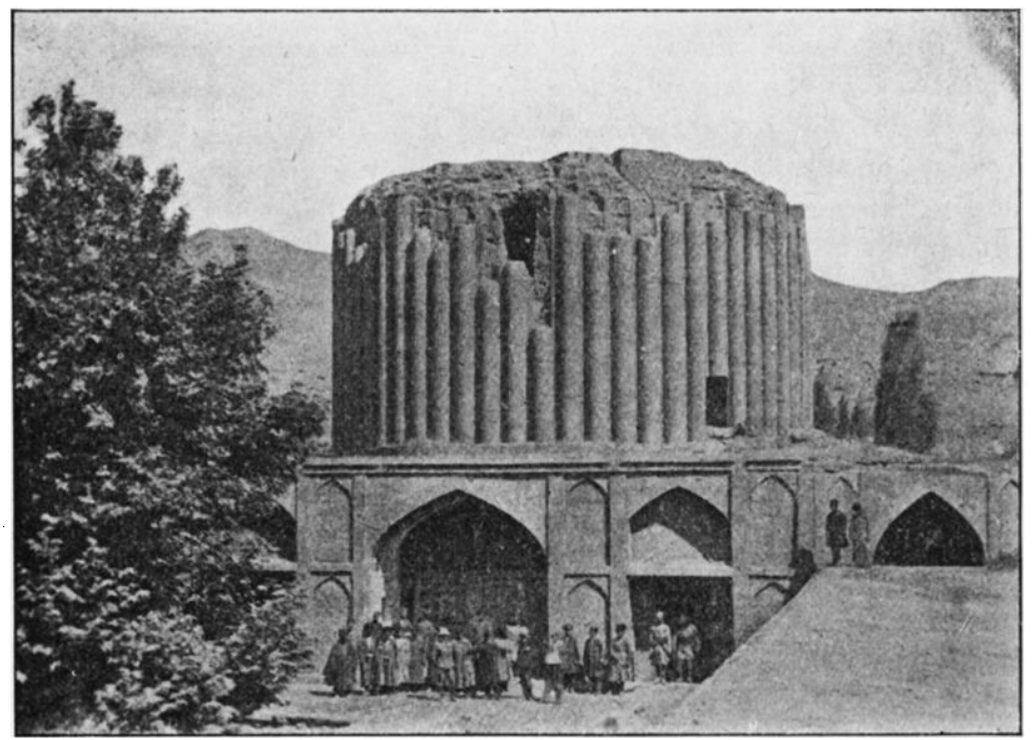

THE TREASURE HOUSE OY NÁDIR SHÁH.

the hamlet of Khist, to the west of which, covering several acres, was the palace in which the family of Nádir Sháh was surprised, in the manner already related. The buildings were of coursed stone, and the ruins of a Persian bath were visible; but here again everything presented the same aspect of incompleteness, and the most interesting remains consisted of elaborate masses of masonry which filled the steep valleys, and were designed to store the water-supply. Indeed, to-day, the villagers depend upon these reservoirs, and their crops are fed by the rainfall, there being no springs or irrigation works on these hills. A second ascent brought us, at an elevation of 6000 feet, to the highest peak of the northern wall. As may be supposed, the view was superb; and, from our point of vantage, we looked down on the great plain of 
Asia, which stretches in unrivalled monotony to the arctic tundra of Siberia, and is perhaps the most extensive in the world. Almost at our feet lay Doshákh, and Kakha, with the Trans-caspian railway, and, to add to our pleasure, we descried a train running on the famous line, the sight of which, the Indian sowars vowed, made them feel homesick, and recalled to me the joy some yeomen in South Africa expressed at the sight of a mining chimney at Klerksdorp. Tearing ourselves away with difficulty from gazing across the yellow plain, we turned our eyes to the great fort. As mentioned above, the northern face is less regular, and appeared to be less impracticable; but we only saw it from the crest, which is here an easy slope, and the lower portion is said to consist of sheer cliff. Looking into the valley, we saw a maze of low hills, which to the south-east terminated in flattopped Kuh-i-Bába-Kumeili. But the day was waning, and we had to hasten back to the valley, where everything felt damp and unwholesome compared with the keen mountain air of Khist.

We camped at Kabud Gunbad, and, making an early start on the following morning, rode east down the valley. The river runs between high cliffs, which are united by a remarkable dam some 90 feet wide and perhaps 250 feet in height. It is constructed of red brick, and is said to date from a period anterior to that of Nádir. A few miles lower down, ruined walls mark the site of the once extensive pleasaunce of the Great Conqueror, and, nearing the natural walls of the fort, we passed Deh Nafta, a village inhabited by Khuzái Arabs, whose ancestors were also brought to this happy valley by the same master mind. Below, the river runs through cliffs which attain to an unrivalled pitch of sullen grandeur. Nowhere have I seen anything to match the impressiveness of this impregnable defile, which repulsed Tamerlane's repeated onslaughts, and fully merits the epithet "awesome" which is applied to it by the Persian historian; and here I bring to a close my description of a visit to Kalat-i-Nádiri, which has stamped ineffaceable recollections on my mind.

We quitted Kalát by the Dehchi darband, the descent to which is extremely rough. We then skirted the Russo-Persian frontier in a westerly direction, passing the historical village of Charam, which, as related by Firdausi, nestles in the hills. That night we camped at the charming village of Archingán, and, early the next morning, we accompanied Sir Arthur Hardinge to the Russian frontier post of Sang-iDivár. Here we were most cordially welcomed by the Russian officer in charge, and said good-bye to the minister, who reached Kahka a few hours later, and London in eight days, so miraculously bas science brought these solitudes of Central Asia into touch with the Western world. Turning our backs with some regret on civilization, Captain Watson and myself rode due south to the lovely hill village of Khákistar, where we camped under superb walnuts and shot at wood pigeons as 
they came in to roost. Khákistar is now the frontier customs post, and there is a great deal of traffic along the route we were to follow back to Meshed, which has, so far as I know, never been followed by any English traveller. The scenery is extremely romantic, being bold though, for once, not forbidding, as the ranges are covered with fine junipers, and in a country like Persia such a sight is refreshing beyond words.

The ascent to the Dalucha pass was extremely steep, but thenceforward we skirted the superb Hazár Masjid range, until we crossed the second of these same mighty spurs, which we had already traversed on the way to Kalát-i-Nádiri ; here the junipers ceased and the hillsides became naked. The stage was nearly 30 miles long, and as we had shot for part of the way, we were glad to reach Márishk, a most picturesque village situated at the junction of the two valleys; it is the headquarters of the Chulai tribe. The following day the scenery was still fine, but nothing to what we had left behind, and a short stage brought us back again to Kardeh. Instead of returning to Meshed direct from Kardeh, we rode to inspect the ruins of Tus, which is one of the most historical cities of Khorasán, but is perhaps chiefly famous in Europe as having been the home of Firdausi. Tus is situated in the same fertile valley as Meshed, of which it is the mother city; but apart from the ruined walls and a dome, which is erroneously considered to be the tomb of the great epic poet of Persia, there is little to mark a city which was the theme of the mediæval travellers. But the bridge is of great surpassing interest, as the legend runs that Mahmud of Ghazni regretted his treatment of Firdausi, and sent him camel-loads of gold as a reward for his great poem. The caravan was, however, met by the bier which bore the poet to his grave. Disdaining to accept the monarch's bounty, the money was used by the poet's daughter to build this bridge, and to bring down a stream of water from the hills. To resume, a few hours were quite sufficient for the examination of Tus, and 13 miles more brought us back to Meshed after a ten days' tour, which was one of the most interesting I have ever made.

VI.

In the late autumn of 1905 we started on a tour which was intended to include the chief centres of Eastern Khorasán, a country with which is connected the names of Valentine Baker, MacGregor, Stewart, and Yate. We left Meshed by the Herát road, and traversed the almost level valley of the Kashaf Rud in a south-south-easterly direction to Jimábád, a thriving village of two hundred houses. Thence we rose gradually to the village of Sangbast, where we found a tent pitched for breakfast. The interest of Sangbast centres in a ruined dome and a lofty column, both built of burnt brick. Round the top of the latter, which is in an almost perfect state of preservation, is a Kufic inscription, which was photographed. Eiáz, the vizier of Mahmud of Ghazni, 
who was contemporary with Alfred the Great, founded these buildings as a college and tomb for a saint named Mirza Abdul Kásim, his religious leader. Until the last generation, there were two of these columns. Two miles beyond Sangbast we camped at the village of Bakirábád, which is inhabited by Yezdis and Kermánis. From Bakirábád we rose steadily for some miles, and, crossing a low range, descended on the plain of Farimán, which is famous in Khorasán for its breed of cattle and general fertility. It was also a favourite place for Turkoman raids, to judge by the numerous towers of refuge which were dotted about like so many pepper-pots. The custom was for the cultivators to fly to these little towers, close the entrance with a stone, and then to stand at bay with their matchlock sticking out of the sole aperture, when they were invariably left alone. We were met close to the village by Captain Watson, who had marched across the range from Turbat-i-Heideri, and who accompanied us throughout this tour.

The six hundred families inhabiting Farimán include Jámis, Karáis, Káinis, and Seistánis.* The fact is, that until the Russians drowned the Turkoman terror in the blood of the man-stealers, these fertile lands were never safe. Nowadays, however, there is a stream of emigration from the less-favoured districts of Persia and Afghanistan, with the result that the prosperity of Khorasán is steadily increasing. The fertility of Farimán depends on its dam, which had recently been repaired by the orders of H.H. the Ain-u-Dola, an ex-grand vizier of Persia. Building was still going on at the time of our visit, although it was merely a case of finishing touches, and we were courteously shown over the works by the Persian field marshal who was in charge. The dam is advantageously situated between two hills composed of a hard rock, just below a point where two or three valleys unite. Its dimensions are: Total length, 366 feet, with a length of actual dam, 160 feet. Its height is 80 feet, and the foundations are sunk to a depth of 28 feet. The width of the masonry, which is faced on both sides with brick, and filled in with boulders set in mortar, is 20 feet. There are two sluices for water, which escapes by a single exit; there is also a flood channel. At the back of the dam is a huge buttress. The work struck me as good, and it will be interesting to see how it stands. If it prove to be a success, it will pay handsomely, and encourage the construction of other similar works.

After examining this fine public work, we rode among low hills to the hamlet of Chahár Gao, which is some 18 miles to the south of Farimán by the direct route. Shortly after our arrival at the hill hamlet, we heard a fusilade, which approached nearer and nearer.

* I may note that both at Meshed and at 'Turbat-i-Heideri, Captains Battye and Watson are taking a number of anthropometrical measurements, which are considered to be of the utmost ethnological importance. 
We were much puzzled as to what was happening, when a crowd of villagers came into sight, escorting a bride to her new home. A mulla led the procession and read prayers, the crowd joining heartily in the responses, and volleys were fired at the pauses. The little bride, dressed in scarlet, was seated on a pony in front of an aged and wrinkled dame, who was apparently her mother, and the entire population of men, women, and children marched along in great excitement and formed the escort. Altogether it was quite an old-world scene, and carried one back to times which are far removed from the bustle of to-day.

Leaving this charming hamlet, we rode to the Kalla-i-Minár, or "Pillar of Skulls" pass, which we crossed at an altitude of 7100 feet. Upon inquiring the origin of this sinister name, we were informed that about a century ago a Turkoman built a tower, the ruins of which we saw, and levied blackmail on all passers-by. Any one who objected to be fleeced was promptly decapitated, and his skull was built into a column-to encourage future travellers. The pass was not difficult, but the stage to Kala Aga Hasan, situated across the next valley, was a very long one, and it was dark before the camp came in. From Kala Aga Hasan, which was in the district of Turbat-i-Heideri, we changed direction to south-east down the direct rou te to Herát, and, at the stage of Himatábád, entered the district of Bákharz. It was near this village that the late Sir Charles MacGregor* had a brush with Turkoman in 1875. The following day we marched down a stream, where we secured a bag of teal and duck, and, camping at the picturesque hamlet of Kabchi, entered Shahr-i-No, the chief village of the district, on the following morning. Bákharz of to-day is divided into three divisions of " Upper," "Middle," and "Lower" Bákharz, which word, it may be mentioned, is a contraction of Bád Harza, or "Where the wind blows." Down this belt sweeps the famous north-north-west wind $\dagger$ of Herát, which in Seistán is known as the Búd-i-Sad-va-Bist-Ruz, or "Wind of 120 days," to which Sir Henry McMahon has paid homage in his recent paper on the delta of the Helmand, it being indeed impossible to ignore it. As a proof of how the wind influences names, we may also cite the neighbouring district to the east of Bákharz, which is termed Bádghis, and is derived from Bád Khiz, or "Wind-stirring." Another point of interest is that this unremitting gale has been used from very early times for grinding grain. Indeed, it is quite possible that, in the mill, we have the prototype of all windmills. At any rate, in Masudi $\ddagger$ there is a story which proves that windmills were known to the Persians at the time of the Arab conquest, which is anterior by many centuries to their use in Europe.

* Vide his 'Journey through Khorasán,' vol. 1, p. 254.

$\dagger$ 'To be exact, it blows from $30^{\circ}$ west of north.

$\ddagger$ Vide his 'Prairies d’Or,' ed. Barbier de Meynard, vol. 4, p. 227. 
I have previously referred to the mixture of peoples in Khorasán, and was consequently not surprised when the leader of our reception party stated that his ancestors were Ansari * Arabs from Medina, who had settled in the district seven centuries ago. The present village is surrounded by extensive gardens, and occupies a site near the ancient Málin, which in the fourth (tenth) century was an important centre. Bad times, however, overtook it, and Málin became the utter ruin it is to-day. Rather more than a century ago, a Hazára chief, Mohamed Khán by name, founded Shahr-i-No, which itself has now been deserted, the peasants, thanks to a cessation of raiding, being now able to live on their own property outside the walls of the fort. Close by the ruin of Málin, or Málan, which covers a large mound, was a shrine in honour of Sheikh Abdulla, son of the famous Sheith Ahmad of Jam, which was sheltered by a solitary but magnificent pine. Bákharz is always considered to be a fertile district of Khorasán. But for seven years locusts have ravaged it, and the population is thoroughly disheartened and is leaving the district, as no organized effort has been made to cope with this terrible curse, which year after year wrecks the happiness and well-being of the industrious sons of Irán. By no means the least evil of the scourge is that it favours the increase of the opium crop, which is not affected by locusts.

From Shahr-i-No we again made for the hills, our objective now being the historical town of Khaf. On our way we visited a large mere, but shooting was a failure, as there was no means of retrieving the birds which fell, owing to the combination of thick weeds and deep water. We consequently turned our backs on the Bákharz valley and marched uphill to the village of Ustá, the inhabitants of which are all Sunnis. Before continuing the march on the following morning, we explored a most interesting fort, known as the Kuh-i-Sangi. In shape it resembles the famous Mil-i-Farhád of Rudbár, which has already been referred to in this paper, and rises some 1500 feet above the plain in the form of a cone. A steep climb brought us to a level summit, oblong in shape, and perhaps 150 feet in length by 40 feet in breadth. There were four tanks, all of them cut in the living rock, the largest being 30 feet square and perhaps 20 feet in depth. It was lined throughout with brick. Below, on the other peaks, were the remains of what is believed to have been stabling and quarters, and the whole much resembled the fort I visited near Duruh in 1899. The march was a series of sharp ascents, with occasional descents to the pass known as the Kotal-i-Kháki, which we reached at 8 miles from Ustá. There is a second pass sone 5 miles to the east, known as Kotal-i-Sangi, but it is practically impassable for laden mules. The altitude of the pass is about 5000 feet. The descent was easy, through fine scenery, to a

* These Arabs were descendants of the party which invited Mohamed to Medina, and have ever since borne the title "the Helpers." 
small village in the Khaf district, which we had entered after crossing the pass. Only a few miles were now left to accomplish, and, riding across a level plain, we soon caught sight of the pines for which the little town of Khaf is famous. Outside the ruinous walls we were met by the usual reception, and found our camp pitched in the open, close to the ruined fort.

The district of Khwaf, as it is spelt, has been of note for many centuries, and was famous for its grapes and pomegranates, which latter fruit cannot stand the cold of the Meshed winter. Its general elevation is so much lower than that of Bákharz that it is deemed to be Garmsir, or "Hot Country." In mediæval times, Salumak, now Salámi, was the capital of the district. To-day $R u-i-K h a ́ f$, or "the Face of Khaf," situated some 3 miles to the north-west of the ancient Khargird, is the chief centre. It is generally termed Rui. The town has suffered in importance from the cessation of raids, and is now half deserted, with but two thousand Sunni inhabitants, all of whom wear a dress which consists of a long coat of quilted light blue calico, resembling the Turkoman garb; but, instead of the sheepskin bonnet, they twist a white puggari round their heads. Curiously enough, too, there has been a tiny colony of Hindus at Kháf for some generations. Although hailing from Shikárpur in Sind, like the Kermán and Bandar Abbás colonies, they have no connection with these latter. They are well treated nowadays by the Persian authorities, but did not appear to be prosperous. Hindus are, however, accustomed to conceal their affluence. The redeeming feature of Khaf is its fine pines, which are said to have been brought from the Himalayas. It gave one a touch of home to hear them soughing in the wind, and efforts are now being made to grow these splendid trees in the Meshed consulate. In the range which lies to the south-west of Khaf, which is known as Khoja Yar, games are held at the No Ruz, the vernal equinox, just as in Seistán.* It is almost certain that this is a survival from pre-Mohammedan days, and, as such, is particularly interesting.

The following morning we visited the once famous madressa of Khargird. $\dagger$ It is a double-storeyed square, with outside measurements of 160 feet by 150 feet. The main gateway is a noble piece of work, inlaid with coloured bricks, and decorated with a blue mosaic inscription. Of this, the right half, consisting of verses from the Koran, was defaced and illegible; but the left half was copied, and is to the effect that Sháh Rukh, aided by Ahmad of Kháf, constructed the madressa in A.H. 848 (A.D. 1444). The interior is built in the usual style round a court with four open arches. The coloured bricks are still intact, but the mosaics, which are exquisite, are almost all defaced. Their colours are sapphire-blue, with yellow, green, and

* Vide, 'Ten Thousand Miles in Persia,' pp. 379-380.

† Khargird is said to be a corruption of Khusru Kard, or " Khusru's Building." 
white, the motive of the pattern being conventional Kufic letters. Captain Watson photographed the best-preserved specimens of this art. Fine mosaic tiles, dark blue, with conventional flowers in light blue, white, and gold, originally covered the interior of the arches; but almost all have been removed, and in a very few years none will be left. On both sides of the main entrance is a domed building, which is decorated with beautiful plasterwork, the paneling to match consisting of white marble hexagons, relieved by sapphire-coloured tiles. This, the finest building which $I$ have yet seen in Khorasán outside Meshed, was the work of Ghiás-u-Dín and of Kawám-u-Dín, both of Shiraz. The latter architect also built the Gauhar Shád mosque of Meshed. The photographs of this erstwhile stately college by no means do it justice, but specimens of the tiles which $I$ was able to procure at Meshed show what a superb building it must have been when Sháh Rukh, son of mighty Tamerlane, received it, in all its glory of blue and gold, from the hands of his architect.

One of my objects in visiting the Kháf district was to complete my general acquaintance with Eastern Persia, and I may perhaps here summarize the various basins or depressions, the last of which, after more than twelve years of travel, I was now visiting. North of the east-to-west ranges of Makrán, which are pierced by various torrents making their way to the Arabian Sea, is the depression of the Mashkel, and further north, again, the main basin of the Helmand, which drains Southern Afghanistan and part of Eastern Persia. These two basins I had examined in 1896 and 1899 respectively. In the latter year, too, on my journey from Sistán to the Káin hills, I had looked across the grim Dasht-i-Naumid, , or " Desert of Despair," itself containing a minor depression, and the Khaf Namaksar, or Salt Lake, is the last of these depressions before the Hari Rud basin, which we were now about to enter, is reached. Khaf was the most southerly point of the tour, on quitting which we marched due east across the level plain, obliquely approaching the range which we had crossed four days previously. At 15 miles there was a low pass in the hills, running down from the main range, which terminated a few miles to the south-east of this point. Crossing the pass, which is termed Dar Darrah, we descended to Karát. This hamlet boasts of a mil, or column, which was of two sizes. The lower portion, some 80 feet in height, was octagonal, and had a belt of much defaced Kufic inscription, which we copied. The upper portion, some 60 feet in height and round, was leaning considerably out of the perpendicular, and looked too dangerous to ascend. A staircase led to the top, and, as elsewhere, this column was undoubtedly used as a signal and look-out station. It is said to have been built

* Captain Keyes, H.M. Consul at Turbat-i-Heideri, states that the word is now pronounced Dasht-i-Nammad. Possibly it is a corruption of Náumid. 
by Sháh Rukh. Close by, are the ruins of a caravanserai and dam. At Karát we were within a few miles of the Afghan frontier, and to reach Kárez we changed our direction from east to north-east, and skirted the western portion of the Hashtadán plain. After crossing a low range of worn-down hills, we reached the little town of Teiobád, which is by far the largest centre of the district of Bákharz, and can boast of 3500 inhabitants. A few miles beyond was Kárez, which is on the main Meshed-Herát road, and the frontier village of Persia.

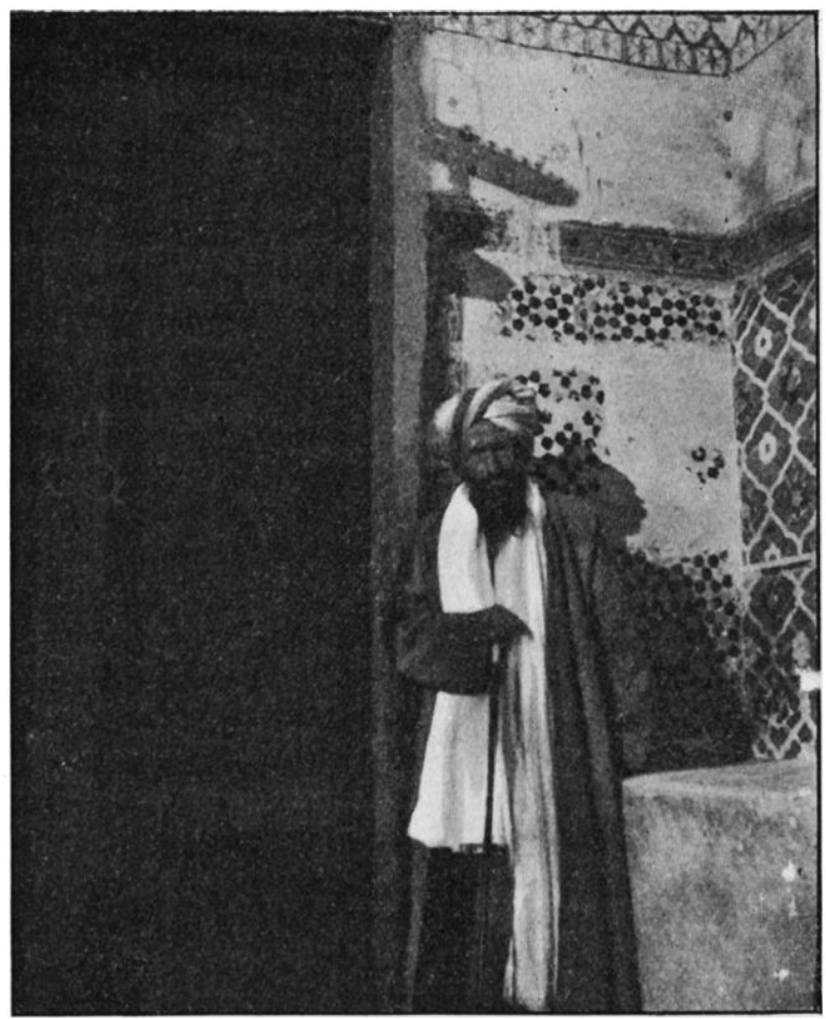

THE KAZI OF TURBAT-I-SHEIKH-JÁM.

Kárez, to judge from the ruins surrounding it, was of importance in the days of yore; and, at any rate, it possesses considerable interest for us, inasmuch it was the birthplace of Hakím Burkai, in whose honour Moore wrote "The Veiled Prophet of Khorasán." I always think that it is interesting to gain touch with these somewhat legendary figures, and to know that in the second (eighth) century the "Veiled Prophet," as the Arabic is rightly translated, gave much trouble to the Caliph Mahdi, but, being eventually defeated, poisoned all his 
followers, and then threw himself into a cauldron of nitric acid rather than submit.

From Kárez we marched north to the Jam river, which, as Sir George Birdwood has pointed out, is the river of Jamshid, "which reveals the present and the future of the world." According to the legend, Jamshid travelled to it every day-here is a form of the Solar myth-and his famous "sever-ringed cup" is, in reality, the Jam Rud reflecting the seven planets, whose revolutions rule the destinies of mankind. For us, arnong its chigf attractions was the hope of some good shooting. Bird-life in Khorasán is scarce compared to what is met with in well-wooded and well-watered England; but, at the same time, there is less of the utter void which is so noticeable in Southeast Persia and the terrible Lut. The Jam river, which we struck at Dolatábád, is drawn off to a great extent for purposes of cultivation, but, nevertheless, holds a certain amount of water, and in places is full of reeds. Consequently the shooting for two guns was excellent, as in the marshy sections snipe, redshank, and mallard, teal, widgeon, and pintail ducks, not to mention shovellers, gadwell, and the ruddy sheldrake, abounded, and there were also large flocks of lapwings. As is so often the case, however, we did not enjoy to the full this excellent sport, as we were within a ride of the famous Hari Rud, which, apart from its other attractions, was said to hold pheasants; and, never having shot a pheasant in Persia, we decided to reserve most of our limited number of cartridges for this purpose. We started off down the Jam Rud at an early hour, and, after a ride of some 14 miles, reached the Hari ${ }^{*}$ Rud, the classical Arius. At the point where we struck it, the river flows in a bed, which is from 2 to 3 miles wide, both banks being covered with tamarisk. The river was some 40 yards in width, flowing with a swift current, and difficult to ford except at a few points. The water is very salt in this section, except after a flood. This, then, is the Hari Rud, which, formed by the junction of two streams in the high country to the east of Herát, flows close to the south of that most historical city, and then, curving round due north, forms the boundary between Persia and Afghanistan for some miles. Lower down, it constitutes the Russo-Persian frontier, and, changing its name to the Tejend, is ultimately lost in the all-engulfing sands.

To resume, we beat the tamarisks for about five hours, but only secured partridges and hares, and, as the day was waning, we returned to the Jam Rud, where we enjoyed good sport, and ultimately reached camp several hours after dark. From Dolatábád, we shot our way up the Jam Rud for some miles, and then made across country to the ancient site of Buzján, which, in the fourth (tenth) century was of considerable importance, and the chief town of the district of Jam, which

* Hari, Herat, the classical Arius, Aria, and Aryan are all one and the same word. 
we bad now entered. There was, however, little to see except a low hill with crumbling walls and bits of pottery, but from it we could descry the lofty gateway of the Jam Shrine, and a few hours later we were camped outside this interesting little town.

Turbat-i-Sheikh-Jam, or " the Tomb of the Sheikh of Jam," to give it its full name, is the first town in Persian territory which was reached by conquerors from the north-east and east; it has consequently borne the brunt of many an invasion. But its fame chiefly depends

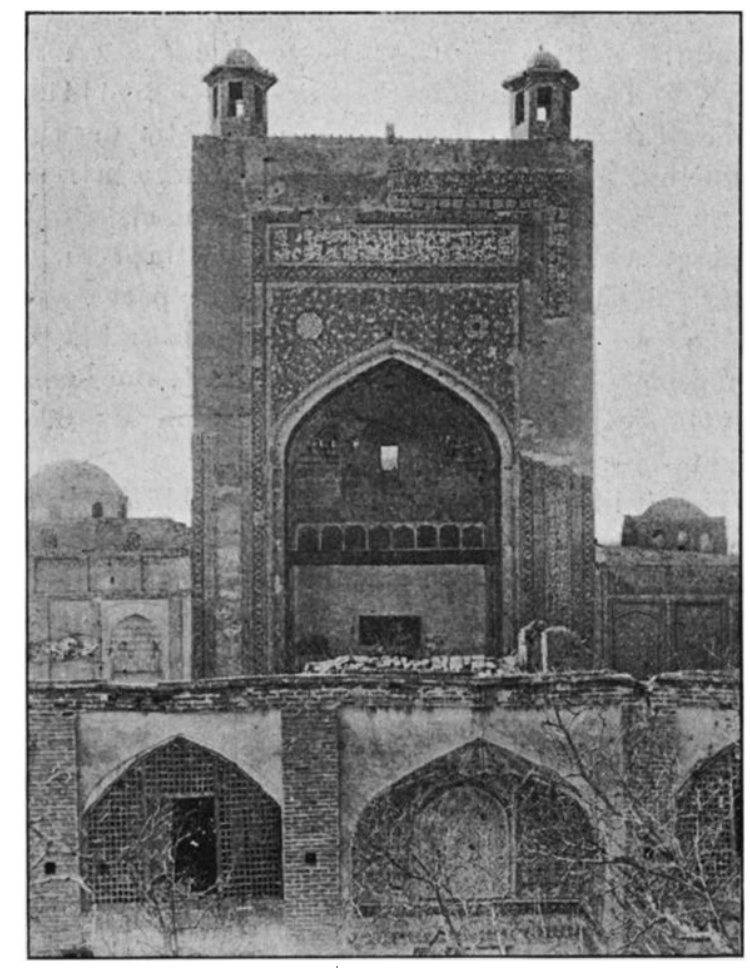

THE SHRINE OF SHEIKH AHMAD AT TURBAT-I-SHEIKH-JAM.

on its having been the birthplace of Sheith Ahmad, and also of the poet Jámi. The former was of Arab extraction, and flourished in the sixth (twelfth) century; he was famous as a religious teacher, his works being still extant. It was in his honour that the shrine was built, and his descendant, known as the Kázi, an old gentleman of ninety, was in charge of this old-world sanctuary when we visited it. The story runs that the shrine was originally built by Sultán Sanjár, the great Seljuk, but that Sháh Abbás destroyed it, on the grounds that the Sheikh was a Sunni. However, a document was produced out of the ruins, from No. VI.-DECEMBER, 1906.] 
which it appeared that the saint was in reality a Shiá, and the penitent monarch vowed that, if he captured Kandahár, he would rebuild the shrine in greater splendour than before. In any case, the great arch referred to above is faced with florid arabesque mosaics in blue and white, with bold yellow scrolls which bear a distinctly Safavi appearance. A strip of blue mosaic with white lettering is the chief motive, but everything is falling into irreparable decay. Indeed, it is remarkable that the tiles should have lasted as long as they have. Behind are two insignificant mosques. The tomb of Sheikh Ahmad is very rude, and his epitaph runs, “A famous teacher, an honoured Sheikh, Ahmad of Jám, a well-known saint. If thou inquirest the year he died, 'Ahmad of Jám, holy is his dust." The last line works out at A.H. 536 (1141), each letter having a numerical value. Close by, is a pathetic inscription of the Emperor Humeiun, then a refugee from India, who married a descendant of the Sheikh. However, his fortune changed, and his dynasty in the person of Akbar the Great was yet destined to leave an imperishable mark on the history of India. Of the poet Abdur Rahman, known as Jámi, we heard little in his birthplace: but his mystical and romantic poems are still famous in the East, and he is held to be the last great classical poet of Persia. He died in A.H. 893 (1487), at the age of eighty-one.

Leaving Turbat-i-Sheikh-Jam, with its venerable Kázi, its crumbling shrine, and its shady garden, we marched north-east across a difficult range for two stages to Khitái, where we again struck the Hari Rud. Soon after leaving camp on the following day, we sighted the remarkable cliffs of Dahána Zulfikar, or “Zulfikar Pass." The legend runs that, Ali cleft it with his forked sword, which the name commemorates. Looking across the river, the cliffs, which offer a singularly good example of erosion in their soft surface, rise sheer to a considerable height, and give the impression of a battlemented wall. Underneath, we sighted the squalid village of Zulfikar, which is held by a sadbáshi* and a fow Afghan frontier guards. Looking up the gorge, our vision was barred by another evenly serrated cliff, closely resembling that of Kalát-i-Nádiri. It was as if a curtain were drawn to prevent the nakedness of Afghanistán being visible to the curious traveller. Perhaps one mile from the gorge, we saw through our fieldglasses two white pillars, which are the actual point where the two empires of India and Russia meet, and from our side of the Hari Rud, barren Irán stretched for hundreds of miles to the west and south, and constitutes yet a third empire. We first came opposite the pass in the white glare so well known to frontier officers; but when evening touched it with her magic wand, each sombre crag was lighted up and glorified by colours of every hue, and it was perhaps at this time that the impressiveness of what is, in reality, the north-western

* A sadbashi is the Oriental equivalent of a centurion. 
boundary of the Indian Empire was for the first time fully realized by us. We camped opposite Zulfikár pass, to enjoy its stern beauty to the utmost; and a short march on the following day brought us to Zorabád, which is a frontier station, and is garrisoned by a small number of Persian troops. Unfortunately it is unhealthy, about one-half of the population having been prostrate with fever a few days before our arrival. Zorabád is inhabited by fifty families of the Organji tribe, who migrated from Khiva a generation ago.

From Zorabád two short stages brought us to the Kashaf Rud, the water of which was extremely salt, so much so that our horses declined to drink it. At Bágh-i-Bághu, however, we at last secured some pheasants, the Phasianus principalis, specimens of which $I$ have given to the Natural History Museum. Here we were within three stages of Meshed, and a few days later returned to our headquarters, after accomplishing yet another tour of great interest, during which I had added considerably to my knowledge of Eastern Khorasán.

In April, 1906, I was granted leave, and, as every hour was precious, I travelled to Kakha in two days, and managed to reach London on the tenth day, after bidding a temporary farewell to the capital of Khorasán.

Before the paper the President: I am dispensed to-night from introducing to you the reader of the paper, Major Sykes, because you all know him. It is now some years since he produced his work on Persia, which was the result of eight years of study there. His name will always be connected with the country of Persia, and I should like, before asking him to read his paper, to indicate the opinion in which he is held by one of the highest authorities in this country on subjects connected with countries in close relation to our great dependency-I mean Lord Curzon of Kedleston, our distinguished Vice-President. Some three weeks ago, speaking at a meeting where Major Sykes was delivering a paper on the Parsees of Persia, Lord Curzon said of Major Sykes, among other complimentary remarks, that there was no living Englishman with a greater knowledge of Persia. Such testimony makes it unnecessary for me to say anything further. I will now call upon Major Sykes to read his paper.

After the paper, the President: I will now call on a member of a profession which is not forbidden to speak to the public. I see here one of its most distinguished representatives, Mr. Chirol, to whom the general public owe a great part of their knowledge of Persian affairs and of the relations of Persia to this country.

Mr. Chirol commented briefly on the terrible state of decay into which Persia had fallen. Every traveller was struck by it, and Major Sykes's paper had afforded fresh evidence of it. The rivalry of Great Britain and Russia had the effect of preventing the Persians from taking the remedy into their own hands, as Nadir Shah and other strong men had done in olden days, who, from time to time, by dint of personal power and measures which we should call revolutionary, pulled the State out of its rut and created a new order of things which continued until another period of decay came, when the process was repeated. "Now," a Persian once remarked to him at Shiraz, "even that resource is taken from us, because the whole effect of the rivalry of the two great powers in Persia is to bolster up a régime which we Persians, who have some knowledge of the conditions in other

$2 \mathrm{R} 2$ 